\title{
MODEL KONSEPTUAL PELATIHAN CEFE UNTUK MENINGKATKAN KEMANDIRIAN UMKM DI KOTA CIMAHI PROVINSI JAWA BARAT
}

\author{
Cucu Sukmana, Ihat Hatimah, Uyu Wahyudin, Ade Sadikin Akhyadi \\ Prodi Pendidikan Masyarakat, Universitas Pendidikan Indonesia, Bandung, Indonesia \\ E-mail: cucusukmana@upi.edu
}

\begin{abstract}
This study aims to to provide a study by describing the conceptual model of CEFE training in perfecting the entrepreneurship training program.method applied is a qualitative approach with Emic's view, then data collection involves MSME actors, assistants, and coordinators as well as data collection tools by observation, documentation, interviews, and tests. Based on the results of the study, it was found that the conceptual model of CEFE training was very helpful in training management and specifically to deal with problems in the business world, then based on the discussion conducted on the conceptual model of the training it was more structured and focused when compared to not implementing the training model, then this management applied real simulation into the world of entrepreneurship which makes this model very suitable to be applied to entrepreneurship training programs. The impact of this research is to create insight into job opportunities, increase entrepreneurial insight and create a family spirit, as well as train participants to develop businesses through business partners.
\end{abstract}

Keywords: Conceptual Model, CEFE Model, MSME

\begin{abstract}
Abstrak
Penelitian ini bertujuan untuk memberikan kajian dengan mendeskripsikan model konseptual pelatihan CEFE dalam menyempurnakan program pelatihan kewirausahaan. Metode penelitian yang diterapkan adalah pendekatan kualitatif dengan pandangan Emic, kemudian pengumpulan data melibatkan pelaku UMKM, pendamping, dan koordinator serta alat pengumpulan data dengan observasi, dokumentasi, wawancara, dan tes. Berdasarkan hasil penelitian didapatkan bahwa model konseptual pelatihan CEFE sangat membantu dalam manajemen pelatihan dan khusus untuk menangani permasalahan di dunia usaha, kemudian berdasarkan pembahasan yang dilakukan mengenai model konseptual pelatihan tersebut lebih terstruktur dan fokus jika dibandingkan dengan tidak menerapkan model pelatihan, kemudian pada manajemen ini menerapkan simuasi nyata ke dunia wirausaha yang membuah model ini menerpkan simulasi model pelatihan, kemudian pada manajemen ini menerapkan simulasi nyata ke dunia wirausaha yang membuat model ini sangat cocok untuk diterapkan pada program pelatihan kewirausahaan. Dampak dari penelitian ini adalah menciptakan wawasan peluang kerja, menambah wawasan kewirausahaan dan menciptakan semangat kekeluargaan, serta melatih peserta untuk mengembangkan usaha melalui mitra usaha.
\end{abstract}

Kata kunci: Model Konseptual, Model CEFE, UMKM. 


\section{PENDAHULUAN}

Pelatihan didefinisikan sebagai "suatu proses yang direncanakan untuk mengubah sikap, pengetahuan, keterampilan atau perilaku melalui pengalaman belajar untuk mencapai kinerja yang efektif dalam suatu kegiatan atau berbagai kegiatan. Tujuannya, dalam situasi kerja, adalah untuk mengembangkan kemampuan individu dan untuk memenuhi kebutuhan organisasi saat ini dan masa depan. Oleh karena itu, "Dengan diklat atau pendidikan seseorang akan lebih mudah dalam menjalankan tugasnya. Adanya diklat atau pendidikan menjamin tersedianya tenaga-tenaga dalam perusahaan yang memiliki keahlian, lagi pula orang yang terlatih atau terdidik dapat menggunakan keahliannya. pikiran kritis.Oleh karena itu, dalam penelitian ini pelatihan kewirausahaan dirasakan sangat penting untuk memberikan bekal berupa pengetahuan dan keterampilan kepada usaha industri kecil dan menengah.CEFE merupakan jenis pelatihan kewirausahaan yang menitikberatkan pada simulasi serupa dengan terlihat di dunia nyata.Tujuan dari pelatihan ini adalah untuk menciptakan wirausahawan baru, memberikan pengetahuan dan wawasan tentang arti wirausaha, serta memberikan inspirasi dan semangat untuk mengembangkan usaha yang mandiri dan profesional sesuai dengan kemampuannya, serta membangun sumber daya manusia yang mampu penciptaan lapangan kerja Mata kuliah kewirausahaan ini berpedoman pada Pasal 19 UndangUndang Republik Indonesia Nomor 20 Tahun 2008 tentang Usaha Mikro, Kecil, dan Menengah serta Pengembangan Sumber Daya Manusia.

Berkaitan dengan permasalahan kewirausahaan di Indonesia, perhatian terhadap industri kecil dan menengah (IKM) sangat penting dalam menjalankan suatu usaha dan tentunya tidak hanya untuk memperkuat struktur ekonomi di tingkat nasional tetapi juga untuk memberikan penyerapan tenaga kerja dan fokus pada strategi strategis. kendaraan untuk dapat menyediakan distribusi barang atau jasa. Pada saat ini perkembangan UMKM sedang mengalami pergerakan perubahan yang signifikan dan mengalami pertumbuhan. Para pelaku bisnis dan UMKM juga menghasilkan beberapa produk yang beragam. Tentunya UKM ini menjadi salah satu terobosan untuk meningkatkan laju pertumbuhan ekonomi yang berjalan di masyarakat untuk mencapai kesejahteraan masyarakat. Berdasarkan hasil observasi lingkungan di wilayah Kota Cimahi dimana produk-produk usaha UMKM unggulan berada, ditemukan banyak potensi yang dapat digali dan dioptimalkan diantaranya lingkungan alam dan lingkungan sosial budaya yang kondusif ( input lingkungan), fasilitas pembelajaran dan pengembangan usaha (instrumental input) yang relatif bervariasi, serta sumber atau input lain berupa permodalan, pasar, dan informasi yang ada di sekitar wilayah Kota Cimahi. Segala potensi sarana tersebut dapat dikelola dan dimanfaatkan untuk meningkatkan kemampuan pengetahuan, sikap, dan keterampilan anggota kelompok dalam mengembangkan kemandirian usaha produktifnya.

Kondisi dan potensi lingkungan Wilayah Kota Cimahi Provinsi Jawa Barat merupakan daya dukung yang dapat dimanfaatkan seoptimal mungkin namun pada kenyataannya sasaran kelompok usaha khususnya pelaku UMKM. Kelompok UMKM masih dihadapkan pada berbagai kendala dalam mengelola usahanya. Secara empiris kendala yang dihadapi masyarakat khususnya para pelaku usaha menyebabkan kurangnya kemandirian pelaku UMKM dalam berwirausaha. Kurangnya kemandirian pelaku UMKM dalam berwirausaha dipengaruhi oleh faktor internal dan eksternal pelaku UMKM. Faktor internal adalah keterbatasan cara pandang pelaku UMKM dalam berwirausaha dan keterbatasan pemahaman pelaku UMKM bidang materi kewirausahaan dalam mengelola kewirausahaan. Sedangkan faktor eksternal adalah banyaknya UMKM dengan produktivitas rendah. Rendahnya kualitas sumber daya manusia, terutama di bidang administrasi, organisasi, keahlian teknologi, dan pemasaran, dapat dikaitkan dengan rendahnya tingkat produktivitas. Selain itu, 
kurangnya faktor masif dan pelatihan CEFE (Competency-Based Economies Through Formation Of Enterprises) yang optimal bagi para pelaku UMKM menyebabkan berkurangnya kompetensi kewirausahaan dan pasar, berkurangnya kemauan untuk bertindak dalam mengembangkan usaha yang layak dengan memanfaatkan prospek yang muncul pada waktu-waktu tertentu dan dalam bidangnya. masing-masing, serta kurangnya sumber daya manusia yang mampu menciptakan lapangan kerja sebagai jawaban atas tuntutan pertumbuhan.

Oleh karena itu, perlu ada treatment pada pengusaha UMKM lainnya, yaitu program melalui pelatihan CEFE (Competency-Based Economies Through Formation Of Enterprises). CEFE telah berkembang menjadi sebuah konsep pengajaran yang berfokus pada premis bahwa pemberdayaan kolektif dapat dicapai terutama dengan penciptaan sumber daya manusia dan pengembangan individu yang aktif dan bertanggung jawab, meningkatkan kekayaan nasional. CEFE telah berkembang dari pendekatan pelatihan individu yang ingin memulai bisnis mandiri dalam metodologi pelatihan yang lebih maju, dibuat untuk membentuk perilaku bisnis (perilaku wirausaha) dan kompetensi dalam situasi yang sangat beragam, oleh karena itu pentingnya program model pelatihan ini perlu diperhatikan. mampu memberikan pelayanan. baik bagi peserta dan dalam model ini juga dapat memberikan materi yang dapat diserap oleh peserta. Dengan demikian, tujuan dari penelitian ini adalah untuk mendeskripsikan pengelolaan program mulai dari perencanaan hingga evaluasi. Program UMKM, yang disampaikan melalui pelatihan CEFE, adalah alat pelatihan holistik yang menggunakan pendekatan berorientasi tindakan dan pembelajaran berbasis pengalaman/pengalaman untuk berbagi dan meningkatkan manajemen bisnis dan keterampilan pribadi dalam komunitas yang beragam, terutama dalam peningkatan. pendapatan dan kesempatan kerja/prospek pekerjaan di Kota Cimahi dan kontribusinya terhadap pertumbuhan ekonomi
Pelatihan menurut Dearden (1984) dijelaskan dalam pengertian luas cakupan istilah pelatihan. Baginya, pelatihan mencakup proses belajar dan mengajar dengan melakukan latihan-latihan untuk mencapai suatu tingkat kompetensi, atau efisiensi kerja. Sejalan dengan itu, saat ini perkembangan kualitas masyarakat perlu ditingkatkan terutama di era digitalisasi dan persaingan pasar global, (Lin et al., 2011) menjelaskan bahwa "teruslah, di era intelektual sumber daya, memiliki pekerja yang luar biasa adalah rahasia untuk meningkatkan kompetensi. Pelatihan adalah praktik dasar bagi bisnis yang mencari pertumbuhan berkelanjutan, dan persiapan pendidikan adalah kurikulum terpenting bagi bisnis yang mencari pembangunan berkelanjutan. Akibatnya, kesiapan pendidikan sangat penting untuk bisnis. Pendidikan dan pelatihan penting tidak hanya untuk mempertahankan dan mengembangkan bakat tetapi juga untuk meningkatkan sumber daya manusia. Kita semua tahu bahwa persaingan di antara perusahaan modern adalah kompetisi bakat".

Adapun pendapat lain terkait dengan konsep pelatihan, (Holst, 2009) berpendapat bahwa "Pelatihan adalah metode penyampaian informasi melalui pemahaman instrumental dan organisasi dari proses pembelajaran dan hasil yang diinginkan. Mayoritas pelatihan difokuskan pada pencapaian tujuan tertentu. Mayoritas pelatihan telah difokuskan di tempat kerja... Pelatihan, di mata banyak pendidik dewasa, adalah kebalikan dari pendidikan." Dalam penjelasannya dijelaskan bahwa pelatihan itu sendiri dilakukan untuk memberikan peringatan kepada masyarakat agar dapat mengembangkan dan menambah wawasan softskill mereka. Sementara itu, pelatihan juga untuk dapat menumbuhkan rasa profesionalisme di masyarakat, dalam hal ini pendapat (Bonnes, 2020) yang menjelaskan bahwa "Persiapan profesional adalah seperangkat latihan yang terorganisir dan sistematis yang membantu peserta pelatihan memperoleh keahlian., kemampuan, dan perilaku yang relevan dengan kehidupan kerja mereka." Dalam pelaksanaan diklat ini tentunya akan 
berdampak positif dan memberdayakan masyarakat untuk meningkatkan kemandiriannya, memungkinkan mereka yang belum pernah memiliki kesempatan untuk mengambil keputusan hidup yang strategis untuk melakukan hal tersebut disebut dengan pemberdayaan. (Ambler et al., 2021).

Kemudian ada kerangka konseptual untuk konsep kompetensi. Dengan demikian kompetensi ini perlu ditingkatkan untuk menambah pengalaman dan pengetahuan masyarakat, hal ini sejalan dengan pendapat (Carracedo et al., 2018) yang menjelaskan pentingnya peningkatan kompetensi "menekankan pada nilai pengembangan kompetensi teknis dan menekankan perlunya program yang membekali siswa dengan keterampilan dasar yang baik dan mengajarkan mereka cara membaca. Sebuah program yang menggabungkan keterampilan dan kompetensi untuk digunakan dalam skenario modern lebih penting daripada yang mengajarkan teknologi mutakhir yang mungkin menjadi usang dalam beberapa tahun.".

CEFE bertujuan untuk melatih peserta secara bertahap dalam keterampilan dan industri kewirausahaan, melatih wirausahawan dan perusahaan, melatih wirausahawan untuk berperan dalam mengembangkan bisnis yang layak dengan memanfaatkan kesenjangan yang muncul pada waktu dan lokasi tertentu serta meningkatkan jumlah orang yang dapat membuka lapangan pekerjaan bagi diri. Tujuan utama dari CEFE adalah untuk meningkatkan keberhasilan wirausaha pada sekelompok pelaku ekonomi dengan menggunakan: 1) self-directed analysis. 2) Mendorong arus bisnis (Enterprise behavior). 3) Mengembangkan keterampilan bisnis. (Komunitas CEFE Indonesia 2019), tujuan khusus :

1. Dapat melatih peserta secara bertahap dengan memiliki kompetensi kewirausahaan dan bisnis.

2. Dapat melatih wirausahawan untuk dapat mendirikan usaha dengan memanfaatkan peluang.

3. Kemudian dapat mengembangkan sumber daya manusia yang akan sangat mampu untuk mampu menciptakan lapangan kerja bagi diri sendiri maupun orang lain

Sedangkan langkah-langkah penerapan CEFE adalah :

1. Langkah pertama: Kesadaran. Langkah awal ini dilakukan untuk mendorong partisipasi dalam mengevaluasi diri, kemudian mengkonstruksi penilaian diri, kemudian introspeksi kepribadian, dan memotivasi diri, kemudian meningkatkan kemampuan dan sumber daya.

2. Langkah kedua: Penerimaan Atau biasa disebut dengan penerimaan dimana untuk kelebihan dan kekurangan yang ada pada dirinya, tidak semua orang bisa menjadi pemimpin tetapi bisa menjadi kreatif, inovatif, dan kompeten, yang merupakan cara untuk bisa mendapatkan penghargaan dari setiap profesi yang dijalani.

3. Langkah ketiga: yaitu fokus pengembangan pada keikhlasan dan "kejelasan tujuan" untuk tujuan panjang atau tujuan pendek.

4. Langkah keempat: Kemudian, setelah meninjau komponen yang relevan dari enam faktor dan termasuk memperbarui informasi yang terkait dengan ekonomi atau pengambilan keputusan bisnis, dapat mencakup merancang strategi dan rencana aksi yang bertujuan menghasilkan kemajuan (wirausaha).

5. Langkah kelima: hands-on experience, yaitu memfokuskan pada implementasi Organized Learning Experiences (SLE) dan menghadapi situasi "kehidupan nyata" dalam kehidupan yang dapat membantu membangun pengalaman dalam menguji strategi yang diterapkan.

\section{METODE PENELITIAN}

Pendekatan yang digunakan dalam penelitian ini adalah penelitian kualitatif, dengan mengutamakan emic view, yaitu menyangkut pandangan informan tanpa paksaan dari peneliti. Pengumpulan data dilakukan dengan wawancara dan observasi partisipan. Untuk subyek penelitian terdapat 30 pelaku UMKM, 3 pendamping UMKM, dan 1 koordinator yang telah berhasil melaksanakan program pelatihan. Pengambilan sampel ini dilakukan dengan 
pertimbangan salah satu alasannya (Purposive Sampling). Untuk penelitian ini, alat dalam pengumpulan data menggunakan beberapa alat, yaitu: (1) pedoman observasi, (2) format dokumentasi; (3) pedoman wawancara, dan (4) tes. Kemudian untuk penilaian dapat dilakukan dengan memberikan pretest sebelum dilakukan proses pendampingan dan dilakukan tes akhir (posttest) atau setelah kegiatan pendampingan selesai, kemudian dilanjutkan dengan membandingkan catatan atau catatan hasil pendampingan. pendampingan peserta kelompok UMKM. memudahkan pendataan di lapangan. Analisis data dilakukan dalam beberapa tahapan, yaitu: authoring, editing, klasifikasi data, reduksi data, interpretasi data, atau interpretasi data. Semua data yang terkumpul dianalisis menggunakan pengkodean data menurut (Strauss \& Corbin, 1990) meliputi proses pengkodean, pembacaan ulang, dan pengelompokan temuan data sehingga diperoleh kelompok data sesuai kategorinya. Para peneliti menyalin rekaman wawancara, diikuti dengan membaca perlahan untuk mendapatkan pemahaman penuh dari sudut pandang informan. Tahapan ini menurut (Fraenkel, J.R., \& Wallen, 2016) dimaksudkan untuk menggali makna dari teks yang telah disusun. Beberapa kategori dibuat dengan menggunakan analisis data triangulasi, dari mana tema muncul, yang kemudian diidentifikasi, dikodekan secara induktif (berbasis data) dari data mentah kualitatif, dan secara deduktif (berbasis teori) dari temuan penelitian sebelumnya. (Chu, PH. dan Chang, 2017).

\section{HASIL DAN PEMBAHASAN Deskripsi Model Konseptual}

Usaha Mikro, Kecil, dan Menengah (UMKM) sebagaimana diatur dalam Undang-Undang nomor 20 tahun 2008 adalah kegiatan usaha yang dapat memperluas kesempatan kerja dan memberikan pelayanan ekonomi yang luas kepada masyarakat serta dapat berperan dalam proses pemerataan dan peningkatan pendapatan masyarakat, mendorong pertumbuhan ekonomi, serta berperan dalam mewujudkan stabilitas nasional. Selain itu, UMKM merupakan salah satu penopang utama perekonomian nasional yang harus memperoleh kesempatan utama, dukungan, perlindungan, dan pengembangan seluasluasnya sebagai bentuk keberpihakan yang kuat dengan kelompok usaha ekonomi rakyat, tanpa mengabaikan peran Usaha Besar. dan Badan Usaha Milik Negara.

Dibalik keberadaan UMKM yang kuat, UMKM menghadapi kendala dalam pelaksanaannya. Masalah paling mendasar terkait pengembangan usaha UMKM adalah rendahnya produktivitas UMKM. Rendahnya produktivitas tersebut disebabkan oleh rendahnya kualitas sumber daya manusia UMKM, terutama di bidang manajemen, organisasi, penguasaan teknologi, pemasaran, dan kompetensi kewirausahaan yang rendah. UMKM juga dihadapkan pada keterbatasan akses terhadap sumber daya produktif, terutama permodalan, teknologi, informasi, dan pasar. Hal ini dikarenakan UMKM umumnya memiliki permasalahan seperti kurangnya akses permodalan, penggunaan teknologi yang relatif sederhana, pengelolaan keuangan yang tidak efisien, kurangnya inovasi, dan manajemen waktu. Selain itu, keterampilan yang diperlukan untuk mendukung inovasi produk dan keterampilan yang dapat diandalkan untuk menghasilkan produk yang benar-benar berkualitas dan terstandarisasi seringkali masih belum dikuasai oleh banyak pelaku UMKM. Kondisi ini menunjukkan pentingnya kemampuan sumber daya manusia yang menjadi kunci utama, yang biasanya dimulai dari pemilik usaha dan tenaga kerja di lingkungan pemilik UMKM. Oleh karena itu, perlu dilakukan pengembangan sumber daya manusia khususnya UKM untuk mengubah perilaku dan meningkatkan kemandirian berwirausaha. Dengan sumber daya manusia yang mumpuni, berbagai langkah kreatif dan inovatif akan tercipta untuk keberlangsungan usahanya. 
1) Pelatihan CEFE (CompetencyBased Economies Through Formation of Enterprises) adalah jenis pelatihan kewirausahaan yang menggabungkan simulasi tambahan yang terlihat di dunia nyata kewirausahaan. Metode ini membahas pengembangan usaha mikro, kecil dan menengah dan memperluas usaha yang ada melalui pengembangan kewirausahaan yang sistematis dan metodologis untuk memulai dan menjalankan usaha. Tujuan pelatihan kewirausahaan ini berdasarkan UndangUndang nomor 20 tahun 2008 pasal 19 tentang pembangunan di bidang sumber daya manusia, yaitu: a) membudayakan dan membudayakan kewirausahaan; b) meningkatkan keterampilan teknis dan manajerial; dan c) mendirikan dan mengembangkan lembaga pendidikan dan pelatihan untuk menyelenggarakan pendidikan, pelatihan, penyuluhan, motivasi dan kreativitas usaha, serta penciptaan wirausaha baru. Konsep CEFE menjadi pilihan penting untuk keluar dan menjawab tantangan permasalahan ekonomi saat ini. CEFE adalah sebuah konsep yang bertujuan untuk melatih peserta secara bertahap dalam kompetensi kewirausahaan dan bisnis, serta wirausahawan untuk dapat membangun bisnis yang layak dengan memanfaatkan peluang yang ada di sekitar mereka. Hal ini juga bertujuan untuk mengembangkan sumber daya manusia yang dapat menciptakan lapangan kerja bagi diri sendiri dan orang lain.

2) Pelatihan kewirausahaan model CEFE dikatakan sebagai konsep ekonomi yang berbasis kompetensi melalui pembentukan kewirausahaan. Pelatihan kewirausahaan ini lebih banyak menerapkan simulasi nyata yang dihadapi dalam dunia wirausaha. Pelatihan CEFE memperkuat proses pembelajaran berdasarkan pengalaman yang telah menjadi ciri khas pembelajaran orang dewasa. Kegiatan pelatihan meliputi peningkatan keterampilan kognitif, keterampilan interpersonal, dan kemampuan adaptif, serta menawarkan kompetensi, informasi, dan seperangkat keterampilan. Pelatihan CEFE menekankan pada pengembangan potensi kemampuan dan kepercayaan diri para pelaku UMKM untuk mencari dan memanfaatkan peluang yang ada dengan pendekatan pengembangan kewirausahaan dan pengembangan usaha.

3) Pelatihan kewirausahaan model CEFE dikatakan sebagai konsep ekonomi yang berbasis kompetensi melalui pembentukan kewirausahaan. Pelatihan kewirausahaan ini lebih banyak menerapkan simulasi nyata yang dihadapi dalam dunia wirausaha. Ada tiga tahapan yang dilakukan dalam pelatihan kewirausahaan model CEFE, yang terdiri dari:

Perencanaan. Tahap ini digunakan untuk merencanakan bagaimana pelatihan akan disampaikan dan masalah apa yang mungkin timbul selama pelaksanaan, seperti mengidentifikasi kesulitan dan menilai kebutuhan; mempelajari lingkungan; menyiapkan komponen pelatihan seperti strategi, administrasi, materi; dan seleksi

4) Pelaksanaan. Tahapan ini dilakukan dengan penyampaian materi oleh instruktur kepada peserta melalui a) penguatan kompetensi pribadi melalui materi ini peserta mengetahui kualitas apa yang harus dimiliki seorang wirausaha, b) pengenalan pribadi dan proyek melalui materi ini peserta dilatih untuk mengenal dan memilih proyek usaha sendiri, c) merumuskan rencana 
usaha melalui materi ini, peserta harus dapat memilih proyek usaha yang diyakini berhasil, mampu melakukan penelitian dan mengembangkannya dalam rencana usaha yang meliputi aspek pemasaran, produksi, organisasi, dan manajemen, serta aspek keuangan, d) penyajian berdasarkan hasil rencana sebelumnya.

5) Evaluasi. Tahapan untuk menilai perubahan kognitif, afektif, dan psikomotorik peserta sehingga dapat ditentukan tindak lanjut yang tepat setelah mengikuti pelatihan CEFE.

\section{Model Rasional}

Pelatihan kewirausahaan memiliki jalur yang jelas dalam proses pembelajaran yaitu mengembangkan potensi dari kemampuan kewirausahaan dari para peserta. Tujuan pelatihan kewirausahaan akan erat kaitannya dengan tujuan kewirausahaan itu sendiri. Menurut Kamil (2012, hlm. 120) beberapa tujuan berwirausaha adalah: 1) mewujudkan ideide inovatif dari seseorang di bidang bisnis, 2) menciptakan sesuatu yang baru dan berbeda di bidang bisnis, 3) mengubah tatanan ekonomi dengan memperkenalkan produk, jasa, menciptakan manajemen, dan mengeksplorasi bahan baku baru dalam bisnis, 4) mengubah tatanan ekonomi dengan memperkenalkan produk, jasa, menciptakan manajemen, dan mengeksplorasi bahan baku baru dalam bisnis 4) tindakan menghasilkan sesuatu yang baru, 5) proses penggunaan kreativitas dan inovasi untuk memecahkan masalah dalam dunia bisnis, 6) Dalam dunia bisnis, menghasilkan ide-ide baru dan menemukan metode baru untuk memecahkan masalah dan memanfaatkan kemungkinan; 7) di bidang bisnis, temukan cara berpikir baru dan lakukan dengan cara itu. Model CEFE dimulai dengan menghubungkan penilaian lingkungan dengan kompetensi peserta, melalui identifikasi, ide, dan pemilihan bisnis. Peneliti mengembangkan model pelatihan CEFE dengan cara a) menganalisis kebutuhan pelatihan peserta, b) menentukan unsur-unsur yang ditentukan, c) mengembangkan model pelatihan CEFE, d) memvalidasi pengembangan model dengan pakar/praktisi pendidikan luar, dan rekan sejawat dan e) menyusun model akhir.

Pelatihan CEFE untuk meningkatkan kemandirian pelaku UMKM dilakukan dengan 1) selalu menggunakan pendekatan andragogi dan partisipatif dalam proses pelatihan; 2) proses pelatihan menggunakan bahasa yang mudah dicerna oleh peserta pelatihan, tidak terlalu ilmiah, sederhana namun sarat pesan; 3) nara sumber menyiapkan dan menggunakan media pembelajaran kontekstual atau sesuai dengan kondisi lingkungan; 4) materi pelatihan kewirausahaan yang disampaikan berkaitan dengan konsep kewirausahaan; 5) tutor saat menjelaskan tentang kewirausahaan disertai dengan memberikan contoh penerapan dalam dunia kewirausahaan; 6) pembahasan materi dilakukan secara kooperatif dan partisipatif; 7) kondisi pengelolaan ruangan yang kondusif, seperti posisi tempat duduk, luas ruangan, ventilasi ruangan, dan media yang digunakan.

Secara umum, dalam pengembangan pelatihan CEFE disepakati kriteria peserta yang dapan berpartisipasi dalam pengembangan model, antara lain:

1) Pernah mengikuti program pendampingan yang telah dilakukan oleh Koperasi dan UMKM dan aktif dalam kegiatannya.

2) Mendaftar Program Pelatihan UMKM.

3) Masa Berwirausaha: Telah terdaftar kurang dari 5 tahun, diutamakan bagi pengusaha yang baru memulai, sehingga dapat dikatakan sebagai pelaku usaha yang baru berkembang dan membutuhkan 
masukan dalam meningkatkan kinerja usahanya.

4) Terdaftar secara informal/formal di Kelompok UMKM Kota Cimahi dan memiliki izin usaha

5) Memiliki prospek produk yang baik di pasar

6) Memiliki omzet di bawah Rp. 1 Milyar/tahun, namun diprioritaskan UKM dibawah Rp. 200 juta/tahun.

Pelatihan CEFE memberikan pengetahuan dan pemahaman tentang ideide kewirausahaan, serta motivasi dan pengembangan taktik rencana bisnis. Pengembangan pola pikir kewirausahaan sangat penting dalam pelatihan CEFE. Bagi UKM, itu berarti mengubah pola pikir atau mindset mereka. Metode CEFE memungkinkan peserta untuk menemukan sendiri poin-poin pengetahuan dan nilai kewirausahaan, mencari dan memilih ide bisnis, pemasaran produksi, aspek keuangan, organisasi, dll., di mana latihan ini tidak hanya memberi mereka berbagai ceramah tetapi mereka harus dimasukkan ke dalam mempraktekkan di lapangan ilmu yang didapat dalam pelatihan dengan bimbingan dan supervisi fasilitator UMKM.

Model pelatihan CEFE dalam meningkatkan kemandirian UMKM ditawarkan sebagai alternatif pendekatan pelatihan pendidikan nonformal. Model ini dibangun dengan menggunakan metode fungsi manajemen, yang melibatkan perencanaan, pelaksanaan, dan penilaian dengan mempertimbangkan banyak komponen seperti proses dan tujuan pelatihan. Model pelatihan CEFE tidak hanya terbatas pada nara sumber/fasilitator yang memberikan materi kepada peserta tetapi juga terkait dengan perlakuan pasca pelatihan. Berdasarkan kondisi faktual, analisis masalah dan kebutuhan pembelajaran serta karakteristik peserta menjadi bahan pertimbangan dalam merancang model konseptual program pelatihan CEFE dalam meningkatkan kemandirian UMKM, seperti digambarkan pada grafik berikut:

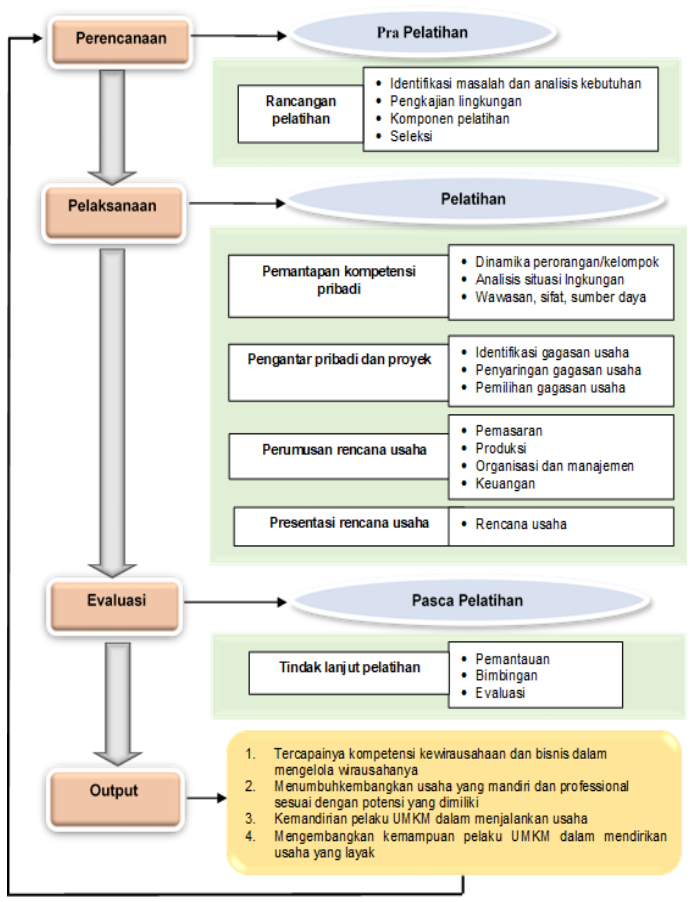

\section{Gambar 1 Model Konseptual CEFE Pelatihan untuk meningkatkan kemandirian UMKM}

Sumber: Analisis Peneliti, 2021

\section{Validasi Model Konseptual}

a. Validasi model bertujuan untuk menghasilkan model pelatihan CEFE yang dapat diterapkan dalam pelatihan, yang berjalan dan dapat meningkatkan kemandirian pelaku UMKM. Dalam prosesnya, model konseptual pelatihan CEFE dibangun berdasarkan studi teoritis dan studi empiris. Namun untuk menguji kelayakan model tersebut, diperlukan beberapa masukan dari berbagai pihak untuk perbaikan, penyempurnaan, dan penajaman model yang telah dibangun.

b. Evaluasi ahli dari model konseptual

c. Validasi ahli Pendidikan Masyarakat dilakukan pada desain model konseptual. Adapun beberapa masukan, 
terkait dengan komponen proses dan keluaran, antara lain: (1) Beberapa materi pelatihan perlu dilengkapi, terutama yang berkaitan dengan pelatihan kewirausahaan, untuk dapat memberikan gambaran nyata tentang kemampuan kontekstual peserta pelatihan. (2) Teknik pelatihan yang memungkinkan peserta didik untuk membangun kemandirian, motivasi, dan minat mereka selama program dan seterusnya. (3) Media yang digunakan dalam pelatihan disesuaikan dengan kondisi peserta pelatihan, dan penggunaan/pemanfaatan media harus sesuai dengan kondisi peserta pelatihan.

(4) Teknik identifikasi atau penilaian yang lebih tepat perlu dikembangkan dalam model pelatihan ini. (5) Evaluasi pemantauan perlu dilakukan selama pasca dan pra pelatihan untuk mengukur keberhasilan perencanaan.

d. Penilaian praktisi terhadap model konseptual

e. Komentar praktisi terhadap model konseptual yang akan dikembangkan menekankan sebagai berikut: (1) Narasumber harus mengetahui atau memahami pendekatan andragogi dalam pelatihan, sehingga perlu adanya pembahasan yang mendalam tentang proses pelatihan yang dilakukan, (2) Peserta diklat sudah memiliki usaha yang dilaksanakan sehingga diperlukan pendekatan khusus dalam proses diklat agar tidak menjadi membosankan, (3) model diklat ini dapat merangkum kebutuhan khususnya yang berkaitan dengan kompetensi diklat, (4) kebutuhan materi dan pendekatan pelatihan yang dianggap inovatif, akan membangkitkan motivasi para peserta pelatihan. (5) Sebagai model pelatihan yang dianggap baru, perlu didampingi untuk pelaksanaan pelatihan selanjutnya. Berdasarkan masukan dari para praktisi tersebut, diperlukan perbaikan dalam penyusunan model pembelajaran dengan memperhatikan hal-hal tersebut di atas, sehingga memudahkan nara sumber/fasilitator dan peserta dalam melaksanakan proses pembelajaran selama pelatihan.

Adapun tanggapan peserta terhadap model yang dikembangkan adalah sebagai berikut: (1) persiapan pelatihan yang tidak membosankan, tidak hanya teoritis tetapi juga aplikatif secara teoritis, (2) beberapa kasus kewirausahaan yang terjadi di kota Cimahi dijadikan bahan diskusi dalam pelatihan tersebut. agar lebih relevan, (3) pemahaman proses skenario pembelajaran dalam pelatihan yang berbeda dengan pola pembelajaran biasanya yaitu learning by doing, (4) model pelatihan ini berdampak positif terhadap kemandirian peserta pelatihan khususnya dalam mendesain usaha yang akan dijalankan, (5) secara bertahap model pelatihan ini memberikan pembiasaan para pelaku UMKM untuk lebih mandiri, menjadi terbiasa menjalankan usahanya, (6) untuk meningkatkan keberlangsungan pelatihan ini perlu adanya pelatihan program atau rutin. Berdasarkan masukan dari calon peserta pelatihan, yang perlu disiapkan adalah skenario pembelajaran yang mudah dipahami oleh peserta pelatihan dan persiapan kelompok sesuai dengan kondisi peserta pelatihan.

\section{Deskripsi model}

Penerapan pendekatan pelatihan CEFE yang layak dan tepat digunakan sebagai prinsip pelatihan yaitu andragogi. Prinsip andragogi dalam desain pelatihan difokuskan pada tiga arah, yaitu: (a) penerapan dan implikasinya terhadap materi pembelajaran pelatihan, (b) penerapan dan implikasinya terhadap metode pembelajaran, dan (c) penerapan implikasinya terhadap manajemen. dari lingkungan belajar pelatihan. 
a) Aplikasi dalam pengembangan materi pembelajaran

Implikasi yang perlu diterapkan dalam pengembangan materi pembelajaran pada pelatihan CEFE untuk meningkatkan kemandirian pelaku UMKM adalah:

1) Mengorganisasikan materi pembelajaran yang menekankan pada komponen pengalaman, persyaratan peserta pelatihan, dan aplikasi praktis.

2) Pemilihan materi pembelajaran dilakukan secara selektif, artinya materi yang diberikan disesuaikan dengan kebutuhan peserta diklat mengikuti hasil need assessment. Hal ini dikarenakan peserta pelatihan adalah orang dewasa yang hanya akan belajar jika materi yang diberikan sesuai dengan kebutuhannya.

3) Penyusunan materi pembelajaran dirancang untuk memberikan kesempatan kepada peserta pelatihan untuk dapat mengembangkan kemampuannya dengan orientasi belajar pada pemecahan masalah kehidupan.

4) Materi harus mengikuti tingkat kemampuan dan latar belakang peserta. Materi pembelajaran harus dapat menghubungkan pengalaman peserta pelatihan dengan materi praktik dan teori yang akan diberikan sehingga manfaat peserta diklat dapat dirasakan.

b) Penerapan dalam metode pembelajaran

Untuk meningkatkan pemahaman peserta tentang nilai-nilai wirausaha, metode yang digunakan adalah ceramah, diskusi, dan demonstrasi. Sedangkan untuk meningkatkan kemampuan peserta menggunakan metode simulasi dan permainan. Implikasi yang perlu diterapkan dalam mengembangkan metode pembelajaran dalam pelatihan CEFE untuk meningkatkan kemandirian pelaku UMKM adalah:

1) Metode yang digunakan harus lebih berupa penemuan atau pemecahan masalah. Instruktur tidak hanya berperan sebagai pemberi informasi tetapi juga berfungsi sebagai fasilitator bagi peserta untuk memperoleh dan mengelola informasi.

2) Penerapan metode yang dipilih harus dipilih dengan penekanan pada peningkatan kualitas peserta pelatihan, peningkatan produktivitas kerja, dan pengembangan keterampilan baru. Metode pembelajaran harus membuat peserta pelatihan mengalami perubahan sikap seiring dengan bertambahnya pengetahuan dan keterampilan.

c) Penerapan implikasi bagi pengelolaan lingkungan belajar pelatihan

Implikasi yang perlu diterapkan dalam mengembangkan pengelolaan lingkungan belajar pelatihan CEFE untuk meningkatkan kemandirian pelaku UMKM adalah:

1) Lingkungan fisik dan psikis yang diciptakan bagi peserta harus kondusif, artinya semua sarana dan prasarana penunjang pelatihan harus dipersiapkan dengan baik dan dipastikan kondusif.

2) Pengaturan dan perlengkapan harus disesuaikan dengan kebutuhan orang dewasa; misalnya, alat bantu dengar dan penglihatan harus disesuaikan dengan kebutuhan fisik orang dewasa. Tata letak ruangan, serta penempatan meja, kursi, dan peralatan, ditentukan oleh isi dan teknik pembelajaran yang digunakan. Telah dicoba untuk menggunakan desain spasial untuk memungkinkan interaksi sosial antara guru dan peserta. Pelatihan dirancang untuk menciptakan iklim belajar yang kondusif, yang dapat mendorong peserta untuk berinteraksi secara sosial baik dengan instruktur maupun dengan peserta lainnya.

3) Dalam kegiatan pelatihan, instruktur lebih membantu dan mendukung. Kembangkan suasana ramah, informal, dan santai melalui kegiatan membangun suasana. Menciptakan suasana demokrasi 
dan kebebasan menyampaikan pendapat tanpa rasa takut.

\section{e. Cakupan}

Pendidikan masyarakat menyediakan lingkungan belajar, mengidentifikasi kebutuhan dalam masyarakat, tidak hanya pertemuan tatap muka dan fisik, tetapi masyarakat berbagi pengalaman dengan orang lain atau kelompok lain. Masyarakat memegang kendali atas pengambilan keputusan, prosesnya berakar pada emansipatoris. Titik tolak pendidikan masyarakat adalah dari pengalaman peserta (masyarakat) yang dihadapi melalui proses refleksi kritis. AONTAS (dalam Connolly, 2003, p.8) menyatakan bahwa pendidikan publik memiliki tujuan yang saling terkait bagi peserta, antara lain:

1. Perolehan keterampilan, pengetahuan, dan pengembangan potensi pribadi

2. Transformasi sosial, komunitas, dan pemberdayaan

Sistem pendidikan masyarakat memberikan kesempatan kepada individu untuk membekali diri dengan keterampilan dan pengetahuan dasar untuk menghadapi lingkungannya (Manullang \& Manullang, 2001: 42). Pelatihan atau training adalah suatu kegiatan yang dirancang untuk meningkatkan kinerja pekerja dalam pekerjaan yang dibebankan kepadanya. Pelatihan berlangsung dalam waktu singkat antara dua hingga tiga hari hingga dua hingga tiga bulan. Pelatihan dilakukan secara sistematis, sesuai prosedur yang terbukti berhasil, dengan metode yang baku dan tepat serta dilaksanakan dengan sungguh-sungguh dan teratur. Menurut Kamil (2012, hlm. 35-36), model pelatihan pemagangan, model pelatihan magang, model pelatihan kerja, model pelatihan literasi, model pelatihan kewirausahaan, model pelatihan manajemen, dan model pelatihan manajemen mutu adalah contoh dari out of -model pelatihan pendidikan sekolah.

Untuk meningkatkan sektor UMKM tentunya diperlukan juga jiwa wirausaha masyarakat sehingga akan muncul wirausaha-wirausaha baru yang dapat menciptakan kegiatan usaha dan menciptakan lapangan pekerjaan. Dengan jiwa kewirausahaan masyarakat, masyarakat akan mampu bertahan dalam kondisi apapun dan mampu mengelola risiko sehingga kegiatan usahanya dapat berjalan dengan baik. Hal inilah yang harus dikembangkan oleh UMKM di wilayah Kota Cimahi agar para pelaku UMKM dapat menjalankan usahanya secara mandiri. Kesenjangan antara pengetahuan, sikap, dan kemampuan mereka yang ada membutuhkan peningkatan kewirausahaan yang benar sehingga mereka dapat mengoperasikan perusahaan mereka dengan lebih baik.

Model konseptual pelatihan CEFE untuk meningkatkan kemandirian UMKM dilakukan secara sistematis dan terencana. Dengan diterapkannya model konseptual, diketahui bahwa pelatihan konseptual yang dilaksanakan tidak dapat dipisahkan dari konsep pendidikan orang dewasa (andragogi). Pelatihan CEFE mendukung pembelajaran berdasarkan pengalaman dengan memberikan kompetensi, informasi, dan keterampilan. Selanjutnya, sebagai semacam interpretasi dan aktualisasi diri dari informasi baru yang mereka terima selama pelatihan, model konseptual ini dapat memunculkan potensi peserta pelatihan (pelaku UKM). Kemampuan inilah yang menjadi ciri bahwa peserta pelatihan mengalami suatu proses belajar. Indikator lainnya adalah materi kewirausahaan yang melekat dalam kehidupan peserta model pelatihan, selain sebagai materi utama dalam pelatihan, penerapan dalam perencanaan pengembangan usaha merupakan strategi pelatihan dalam meningkatkan 
kemampuan peserta dalam mengelola usahanya untuk menjadi lebih mandiri.

Memperhatikan model konseptual, ternyata tujuan pelatihan CEFE bagi pelaku UMKM tidak hanya untuk meningkatkan pengetahuan, kemampuan, dan sikap seseorang tetapi juga untuk mengembangkan bakat yang dimiliki sehingga dapat melakukan tugas sesuai kebutuhan. Tujuan pelatihan adalah agar pekerja menguasai informasi, keterampilan dan perilaku yang ditekankan dalam program pelatihan dan menerapkannya dalam operasional seharihari," menurut Cut, Z. (2004). Hal ini menunjukkan bahwa pelatihan ditujukan kepada pekerja atau staf dan bahwa dalam penelitian ini, pelaku UMKM mampu mempelajari informasi, keterampilan, dan perilaku yang ditekankan dalam program pelatihan, dan menggunakannya dalam operasi sehari-hari.Pelatihan tersebut memiliki dampak yang signifikan terhadap entitas yang bertanggung jawab, yaitu Dinas UMKM.

Langkah-langkah dalam upaya yang dapat dikembangkan dalam pelatihan ini sama dengan teori Sudjana, dengan beberapa pengecualian: 1) Identifikasi kebutuhan pelatihan, sumber, dan hambatan dikelompokkan dalam perencanaan kegiatan yang dilengkapi dengan perencanaan berbasis pelatihan kewirausahaan berdasarkan karakter peserta yang adalah pelaku UMKM. Identifikasi kebutuhan dan kendala sumber daya, materi kewirausahaan, pengumpulan jadwal, penyusunan pedoman kegiatan, persiapan panggilan peserta, dan persiapan administrasi pembelajaran merupakan bagian dari proses perencanaan. 2) Pelaksanaan pendidikan dan pelatihan, yang dilaksanakan secara berurutan dan berkesinambungan dengan menggunakan metode andragogi, dan 3) evaluasi. Dalam kegiatan evaluasi ini, para peserta diminta untuk membuat rencana wirausaha sesuai dengan minatnya. Rencana tersebut dibuat dalam garis besar konsep yang dituangkan dalam bentuk template kewirausahaan.

Tercapainya kemandirian pelaku UMKM melalui pendekatan CEFE merupakan output dari pelatihan ini. Pelaku UMKM seringkali mengalami kesulitan dalam mengembangkan usahanya karena dihadapkan pada masyarakat dan kondisi lingkungan yang membuat mereka memiliki kemampuan untuk bertahan dalam menjalankan usahanya. Hasil dari pelatihan CEFE ini telah memungkinkan para pelaku UMKM untuk menangani pengembangan usaha mikro, kecil dan menengah serta mengembangkan usaha yang sudah ada melalui pengembangan kewirausahaan yang sistematis dan metodologis untuk memulai dan menjalankan usaha. Menurut E. Sikula (1981, hlm. 235), empat prinsip belajar dalam proses pelatihan adalah sebagai berikut: 1) Setiap orang dapat belajar. Individu dari segala usia dan kapasitas intelektual dapat mempelajari perilaku baru; 2) Seorang individu harus dimotivasi untuk aktualisasi diri, kemajuan, dan insentif moneter; Belajar adalah proses aktif, bukan pasif. Pendidikan yang efektif membutuhkan tindakan dari semua siswa. 3) Dengan supervisi, peserta dapat mempelajari informasi lebih cepat. Karena belajar dengan coba-coba memakan waktu dan tidak efisien, umpan balik diperlukan; 4) konten yang sesuai harus disediakan. Guru harus memiliki berbagai alat dan sumber pelatihan, termasuk contoh, masalah, pertanyaan diskusi, dan bahan bacaan, serta waktu untuk mempraktikkan ajaran. Peserta harus memiliki banyak waktu untuk menyerap, menilai, menerima, dan meyakini materi pelajaran sebagai bagian dari proses pembelajaran; teknik pembelajaran harus bervariasi untuk menghindari kebosanan, dan 5) Peserta 
harus puas dengan pembelajarannya. Kebutuhan, keinginan, dan harapan peserta harus dipenuhi melalui pendidikan.

Pemilihan metode pelatihan CEFE sebagai metode implementasi dengan mempertimbangkan fitur-fitur berikut:

1) Mengharuskan peserta untuk membuat rencana bisnis aktual yang ingin mereka lakukan segera setelah pelatihan selesai.

2) Menyampaikan konsep-konsep kewirausahaan melalui kegiatan eksperimentasi dan pelatihan pengetahuan yang disajikan melalui pendekatan andragogi. Metode pengetahuan aktivitas memungkinkan peserta menemukan sendiri poin pengetahuan dan nilai kewirausahaan, mencari dan memilih ide bisnis, pemasaran produksi, aspek keuangan, organisasi, dll., di mana latihan ini tidak hanya memberi mereka berbagai ceramah tetapi mereka harus berlatih di lapangan ilmu yang didapat dalam pelatihan dengan bimbingan dan supervisi fasilitator UMKM.

3) Metodologi CEFE menekankan pada pembinaan kompetensi peserta pelatihan sehingga peserta dapat merasakan sendiri manfaatnya setelah mengikuti pelatihan.

Tujuan dari pelatihan CEFE ini adalah: 1) Tercapainya kompetensi kewirausahaan dan bisnis dalam mengelola kewirausahaan; 2) Mengembangkan usaha yang mandiri dan profesional sesuai dengan kemampuannya; 3) meningkatkan kemandirian pelaku UMKM dalam menjalankan usahanya, dan 4) mengembangkan kemampuan pelaku UMKM dalam membangun usaha yang layak. Tujuan pendidikan dan pelatihan agar perilaku peserta lebih kreatif dan inovatif dalam menghadapi masa depan dengan berbagai tantangan (Pegawai Pusdiklat Depdiknas, 2003:1). Jadi pengertian, tujuan, dan manfaat dari pelatihan CEFE ini pada hakekatnya merupakan wujud dari kegiatan pelatihan melalui pengembangan potensi sumber daya manusia di bidang kewirausahaan. Pelatihan CEFE bagi pelaku UMKM merupakan kegiatan proses pembelajaran, baik teoritis maupun praktis, yang bertujuan untuk meningkatkan dan menumbuhkan kompetensi atau kemampuan akademik, sosial, pribadi, keterampilan, dan sikap.

\section{KESIMPULAN DAN SARAN}

Berdasarkan dalam pelaksanaan pelatihan berbasis model CEFE telah dilaksanakan dengan sangat baik dan implementasi model CEFE dapat dikatakan sangat bermanfaat dan dapat diserap oleh peserta program pelatihan ini, mengingat banyak peserta setelah mengikuti program sudah mandiri dan kemudian dapat mengembangkan usahanya secara pribadi, selanjutnya untuk penerapan model ini juga dapat dikatakan mengikuti kebutuhan masyarakat. Kompetensi pribadi, perkenalan, dan proyek pribadi, pembuatan dan presentasi rencana bisnis adalah beberapa topik yang dibahas dalam materi pelatihan. Pelaksanaan program pelatihan Manajemen Model CEFE, sangat mengubah pelaku usaha di wilayah Kota Cimahi, kemudian dengan adanya program tersebut juga sangat membantu untuk mendongkrak perekonomian masyarakat dan mengembangkan potensi yang ada khususnya untuk membantu meningkatkan kemandirian masyarakat. masyarakat dalam menjalankan usahanya. Sementara itu, CEFE telah berkembang menjadi konsep pengajaran yang berfokus pada pemberdayaan kolektif yang dapat dicapai terutama dengan meningkatkan sumber daya manusia dan mengembangkan individu yang aktif dan bertanggung jawab yang menghasilkan peningkatan pendapatan masyarakat. Setelah pelatihan dan tindak lanjut dapat dilakukan yaitu monitoring perkembangan usaha peserta 
dan peserta masih harus dibimbing untuk peserta selanjutnya, beberapa tindak lanjut. Kemudian untuk penelitian selanjutnya diharapkan dapat menekankan proses pelaksanaan program pelatihan dan dampak Model CEFE terhadap keberlanjutan program pelatihan kewirausahaan bagi masyarakat.

\section{REFERENSI}

Akdon, (2011). Manajemen Strategis Untuk Manajemen Pendidikan. Bandung: Alfabet.

Arikunto, S. (2004). Dasar-Dasar Evaluasi Pendidikan. Jakarta: Bumi Aksara

Arikunto, Suharsimi., \& Lia Yuliana, (2009). Manajemen Pendidikan. Yogyakarta: Aditya Media memahami dengan Fakultas Ilmu Pendidikan (FPIP) Universitas Negeri Yogyakarta (UNY)

Daryanto, SS. (1998). Kamus Lengkap Bahasa Indonesia. Surabaya: Apollo Lestari.

Gunartin, DKK. (2018). Pusat belajar masyarakat sebagai tempat alternatif menumbuhkan kemandirian wirausaha warga belajar. Jurnal: Pendidikan, ekonomi dan bisnis. 3 (2) 30-48. Diakses pada 13 Oktober 2020 .

Hasibuan, SP. (2004). Manajemen. Jakarta: PT. Bumi Aksara

Irmawati, A. (2017). Peran pusat kegiatan belajar masyarakat (pkbm) dalam pengurangan buta aksara di kabupaten karimun. Jurnal: Pendidikan dan Kebudayaan. 2 (1) 81-89. Diakses pada 13 Oktober 2020 .

Kamil, M. (2003). Model-model Pelatihan. Universitas Pendidikan Indonesia Bandung: Tidak Diterbitkan

Kamil, M. (2009). Pendidikan Nonformal. Bandung: Alfabeta.
Pidarta, Made, (2005). Perencanaan Pendidikan Partisipatori dengan Pendekatan Sistem. Jakarta: PT. Renik Cipta.

Maswan. (2015). Manajemen peningkatan mutu sekolah. Jurnal: Tarbawi 12 (2) 195-204). Diakses pada 13 oktober 2020

Moleong, Lexy J. (2007) Metodologi Penelitian Kualitatif. Penerbit PT Remaja Rosdakarya Offset, Bandung

Rizka, M.DKK. (2018). Program Pelatihan Evaluasi Pendidikan Nonformal Bagi Pengelola Pusat Kegiatan Belajar Masyarakat (PKBM) di Kecamatan Gunungsari Kabupaten Lombok Barat. Jurnal: Paradharma 2 (1) 15-23. Diakses pada 13 Oktober 2020.

Shofwan, I \& Kuntoro, S. (2014). Pengelolaan Program Pembelajaran Pendidikan ALternatif Komunitas Belajar Qaryah Thayyibah Di Salatiga Jawa Tengah. Jurnal: Pendidikan dan Pemberdayaan Masyarakat. 1 (1), 51-62. Doi: http:// garuda.ristekbrin.go.id. Diakses pada 13 Oktober 2020.

Sudjana, D. (2001). Pendidikan Luar sekolah. Bandung: Produksi Falah

Sudjana, D. (2004). Manajemen Program Pendidikan (Untuk Pendidikan Nonformal Dan Pengembangan Sumber Daya Manusia). Bandung: Produksi Falah

Sudjana, D., (2010). Manajemen Program Pendidikan: untuk Pendidikan Nonformal dan Pengembangan Sumber Daya Manusia. Bandung: Falah Production.

Zaini.Hisyam. 2015. Strategi Pembelajaran Aktif. Yogyakarta: Pustaka Insan Madani 